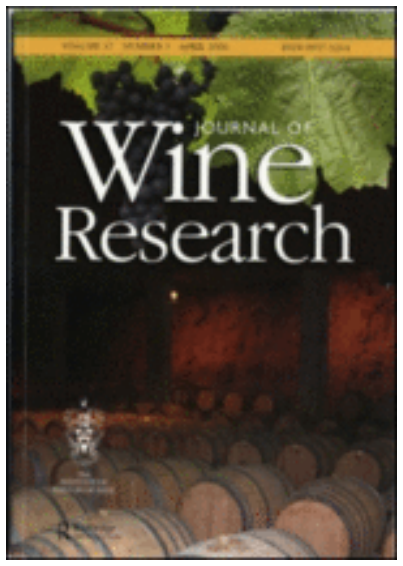

\title{
Rhode Island and Connecticut Wineries Business Strategy, Performance, and Management Capabilities: a Survey of Managerial Practices
}

\begin{tabular}{|c|c|}
\hline Journal: & The Journal of Wine Research \\
\hline Manuscript ID & CJWR-2018-0057.R1 \\
\hline Manuscript Type: & Original Article \\
\hline $\begin{array}{r}\text { Keyword/Research Interest - } \\
\text { General: }\end{array}$ & New world, winery/ies, management capabilities \\
\hline $\begin{array}{r}\text { Keyword/Research Interest - } \\
\text { Geography: }\end{array}$ & USA \\
\hline $\begin{array}{r}\text { Keyword/Research Interest - } \\
\text { VITI/VINI: }\end{array}$ & small wineries, sustainability \\
\hline $\begin{array}{r}\text { Keyword/Research Interest - } \\
\text { Man/Marketing: }\end{array}$ & business vision, critical success factors, product differentiaition \\
\hline \multicolumn{2}{|l|}{$\begin{array}{r}\text { Keyword/Research Interest - } \\
\text { Grape Varieties: }\end{array}$} \\
\hline \multicolumn{2}{|l|}{$\begin{array}{r}\text { Keyword/Research Interest - } \\
\text { Wine Names: }\end{array}$} \\
\hline \multicolumn{2}{|l|}{$\begin{array}{r}\text { Keyword/Research Interest - } \\
\text { Wine Tasting: }\end{array}$} \\
\hline $\begin{array}{r}\text { Keyword/Research Interest - } \\
\text { Economics: }\end{array}$ & statistics, regional ecomomy, quantitative analysis \\
\hline
\end{tabular}

\section{SCHOLARONE ${ }^{m}$ \\ Manuscripts}




\title{
Rhode Island and Connecticut Wineries Business Strategy, Performance, and Management Capabilities: a Survey of Managerial Practices
}

\begin{abstract}
The world wine sector has been greatly changing in recent years; its level of competitiveness is on the rise. In this new environment, many small businesses are joining the industry and developing their activity in geographical regions with less wine tradition. These new wineries in less traditional wine regions have broadened the concept of the industry by linking it with tourism; perhaps with more strength than in other more traditional areas, where this change in the business model has also occurred. To understand what the drivers of a better performance to this new typology of wineries are, this article has surveyed the wineries of the states of Connecticut and Rhode Island, in the northeast of the U.S., a new wine region in the world. Through a questionnaire, the strategies these wineries follow and their relevant management capabilities in relationship with their performance have been analyzed. The conclusions show how the management capabilities the wineries own are as important as the strategy of differentiation they follow in their pursue and obtention of a competitive advantage; and that it is a service and tourism-oriented strategy that eventually facilitates this advantage. The managerial skills of creating an efficient and coordinated organizational structure together with their conception of this service-oriented business, where the tourism aspect plays a fundamental role, seems evident when defining the resources and capabilities that generate their sustainable performance.
\end{abstract}

Key Words: Wine, Competitive Advantage, Business Strategies, Management Capabilities, Performance, Tourism 


\section{Introduction}

The wine and its elaboration present elements that make it especially interesting, it is not only a product, but it is also a way of understanding life for both those who produce it and for those who consume it. For producers, wine contributes elements of conspicuous production (Overton and Banks, 2015) and for consumers, wine is linked to moments of quality of life enjoyment, which can be expressed both at home and in a restaurant, or by enjoying a wine tourism activity.

In newer wine-producing regions the wine industry developed focuses on this dual objective, on the one hand allowing the cultivation of the vineyard and winemaking practices, while in the other, developing a wine tourism business through the contact of producers and consumers in a natural environment presided over by the vineyards and the winery (Byrd et al., 2016). The proliferation process of the development of the U.S. wine sector has been described in detail by Swaminathan (1995). The author highlights as one of the main causes of this blossoming of the wine industry in the U.S. the formation of a niche market due to changes in consumer preferences. One of the elements that strengthen this niche formation in the market is tourism related to wine. Tourism has a strong link to the growth of local industries (Byrd et al., 2016), and small wineries are known to have more involvement (or reliance) on wine tourism than medium-size and larger enterprises (Bruwer, 2003).

One of the areas in which there has been a development of these characteristics is in the northeast of the United States, specifically in the states of Connecticut and Rhode Island. In these two states there are only 47 registered wineries, and the US Alcohol and Tobacco Tax and Trade Bureau (within the U.S. Department of Treasury) has defined two American Viticultural Areas: the South-Eastern New England (parts of Connecticut, Rhode Island, and Massachusetts) and the Western Connecticut Highlands (Villanueva and Moscovici, 2016). It is interesting to note that these two U.S. states were the only ones who voted against the U.S. Constitutional Eighteenth Amendment, which resulted in the prohibition of alcohol consumption and distribution in the country, from 1919 to 1933 (Cohn and Davis, 2009).

The wineries in CT and RI are usually small companies, which make a large part of their sales directly to the consumer after attracting the customer to the winery. The winery constitutes a place of tourist visit, which has festive nuances, of a celebration of a family, social event or a place to meet with neighbors or friends. The wineries hold concerts, yoga days, sporting or cultural events, a tasting or meal is included where the purchase of wine is encouraged through offers, a customer's club or a loyalty program. With this same objective the wineries, or some of them, have opening hours adapted to weekends, holidays or seasons of special tourism activity. In the case of Connecticut and Rhode Island, the proximity to two important population centers, such as New York and Boston, facilitates the development of this wine tourism phenomenon. In these states, wine tourism is a vital part of the birth and growth of their wine industries. The New England wine industries' structural dimensions are directly linked to involvement on wine trails; this participation determines the nature and scope of the wine tourism product provided (Villanueva and Moscovici, 2016). 
This double conception of the wine business, the binomial of the wine as a consumer product and its tourism associated with the wineries, which in this area has a major component, has been developed around the world with different intensity. In settled wine-growing areas in the United States such as California or Oregon, or Europe such as France, Italy, or Spain, wineries promote their tourism component; they prepare visits, gastronomic routes and other events, aware of the importance of bringing the customer closer to the winery to encourage purchase, but also as an element that transforms wine consumption into a unique and playful experience, a circumstance that makes the consumer loyal.

Villanueva and Moscovici (2016) show that this new wine region in New England is relatively young, its wineries test with several grape varieties, and often buy grapes or juice from other wine regions in the country or abroad. Wineries are SMEs (Small and Medium-sized Enterprises) that focus on marketing to tempt visitors for sales at the winery. They also focus on the tourism of wine as the primary economic activity; it is through collaborative marketing efforts of wine associations, wine trails, passport programs, and regional heritage branding that wineries in these regions can survive.

It is then of great interest to do a study of competitiveness to describe and analyze the competitive advantages of wineries of Connecticut and Rhode Island. This should highlight key elements of their strategic intent and make it a case to a large part of wineries that seek to combine wine and tourism.

The study of the competitive advantage of companies is based on their capacity to create greater value than their competitors (Branderburguer, 1996; Besanko et al., 2009). The way the company achieves this competitive advantage has two schools of thought. The first is based on the strategic position that the company adopts in the market (Porter, 1980), the second in the resources and capabilities that the company has and that differentiate it from its competitors by providing it with advantages when competing and appropriating of the rents of its prevailing position (Wernerfelt, 1984; Barney, 1991). These two approaches, one that seeks competitiveness outside the company or in the sector of business and another that does the search of competitiveness in the interior of the company and its provision of resources, are not two incompatible approaches (Spanos and Lioukas, 2001). Numerous studies have shown that the joint analysis facilitates a better understanding of how competitive advantage is produced and achieved, as shown in studies in various industries (Rivard et al., 2006; Rapp et al., 2010; Takata, 2016; Rosenberg and Ferlie, 2016; Chuang and Lin, 2017), and in the wine sector (Ferrer et al., 2018a).

In determining the preeminent factors for wineries in Connecticut and Rhode Island to acquire their competitive advantage, this article follows this double approach: the Theory of Competitive Advantage (Porter, 1980) and the Theory of Resources and Capabilities or Resource Based Theory (Barney, 1991). The achievement of a competitive advantage means the creation of greater value for the winery, which is reflected in better performance indicators (Amadieu and Viviani, 2010; Simon-Elorz et al., 2015). At the same time and in terms of internal resources and capabilities to obtain this competitive advantage, management capabilities are also studied, with research that analyzes this internal capital to be the most important in determining the best results of companies in various business sectors (Teece et al., 1997; 
Spanos and Lioukas, 2001; Ortega, 2010), and the wine sector (Remaud and Couderc, 2006; Kunc, 2007; Torres and Kunc, 2016).

This article comes to cover gaps in knowledge. The role of resources and management capabilities in obtaining a competitive advantage in the wine sector in the United States has been scarcely studied, i.e.: Taplin (2006) studied wineries in Napa Valley and their strategy modification because of incremental competition. There are a few other cases of studies using this approach in regional or country-level wine industries analysis. Kunc (2007) performed a study on managerial practices in the Chilean small and medium wineries, Chartes et al. (2008) completed a survey on the managerial practices in the Australian wine sector SMEs, Duarte and Bressan (2016) did the same in a study in the Italian wine sector SMEs, and Ferrer et al. (2017) studied the competitive advantage differences between firms belonging to a business group and independent wineries in the Spanish wine industry, while Ferrer et al. (2018a) analyzed the competitive advantage and general performance factors found in wineries belonging to the Spanish wine industry, and Ferrer et al. (2018b) focused their study on the application of the Miles and Snow model in wineries of the Spanish wine sector.

In the context of this new wine region, this article intends to determine what are the major drivers of performance, whether a clear strategic intent or their management capabilities, or both. Eventually, in a second analysis, what strategic intent and what managerial skills are preeminent in the management of these wineries. Studying wineries in New England is unique and a novelty that may give clues in the understanding of the wine industry of new and burgeoning wine regions.

The article is structured as follows: section 1 presents the theoretical framework; section 2 explains the three hypotheses: one focuses on management capabilities, and two in the firm's strategy; section 3 shows the sample and variables; section 4, the methodology used; section 5 reports the results; lastly conclusions are presented.

\section{Theoretical Framework}

The theoretical analysis of the factors that determine the competitive advantage of wineries in Connecticut and Rhode Island is developed following the aforementioned theories: the Theory of Competitive Advantage (Porter, 1980) and the Theory of Resources and Capabilities or Resource Based Theory (Barney, 1991).

Porter (1980) argues that the company that can obtain a competitive advantage is one that can find a position within the industry by developing a strategy that allows it to defend themselves of their competitors. To determine this position, the company must perform the strategic planning process. There are only two main generic strategies, Differentiation (benefit leadership) or Cost (cost leadership); differentiation implies that the company's products can be sold with a price premium relative to competitors, the company focusing its efforts in any attribute but price, while cost leadership is when the company's products can be produced at a lower cost per unit than competitors, the company focusing its efforts in the attribute of price (Besanko 
The resources and capabilities available to the company are not in themselves a strategic and fundamental element that ensures the achievement of competitive advantage. Three conditions must be fulfilled to obtain it: establishing and maintaining the competitive advantage and appropriating the benefits that arise from it. Resources must be scarce and relevant to satisfy these three conditions, and they must be durable, nontransferable, and not replicable (Grant, 2010).

\section{Hypotheses}

\section{Competitive Strategy and Business Performance}

The strategies that the company adopts, following the Theory of Competitive Advantage (Porter, 1980), are leadership in cost or differentiation, or any of those two but focused in a segment of the market. The analysis of the strategic activities of the company contemplates the whole series of competitive decisions that the company adopts in the search for a competitive advantage and that shapes its strategy (Ortega, 2010; Barney et al., 2011). To study the achievement of a competitive advantage of the Connecticut and Rhode Island wineries, the strategies adopted to do so are analyzed through the methodology of Robinson and Pearce (1988), analyzing their orientation towards cost leadership or differentiation (Dess and Davis, 1984).

In the effort to achieve survival and success, the company is projected outwardly defining its strategy, which products to offer, and in what market to offer them (Ansoff, 1965). The vision, mission, and values of the company determine their objectives which will involve the definition of their place in the market (Brenes et al., 2014).

Although there has been extensive research written about strategy in terms of business, Porter's perspective (1980 and 1985) continues to be the one that receives the greatest consensus in articles, textbooks (Campbell, 2000), and empirical studies (Campbell, 2000; Spanos and Lioukas, 2001; Camisón and VillarLópez, 2014; Ortega, 2010; Brenes et al., 2014). Porter conceives the determination of the strategy as the analysis of the competitive behavior, and the choice between two generic strategies, leadership in cost or differentiation, and the existence of an eventual third as the projection of any of the two on a certain segment. The scheme leads to an increase in the value created by the company either by increasing the 
perceived profit or by reducing production costs and thus improving its competitiveness (Besanko et al., 2009).

In the wine sector, these strategies have been effective in different competitive environments. The differentiation strategy has been linked to better business performance in the cases, among others, of French Bordeaux wines or California wines (Taplin, 2006; Cox and Bridwell, 2007; Berríos and Saens, 2012). The segment differentiation strategy has also been highlighted in the strategic behaviors of small wineries, they can compete whenever they focus their efforts in a market niche (Remaud and Couderc, 2006).

On the other hand, the cost strategy has been linked to the success in the emergence of Australian wine in the U.K. and the U.S., shown in the emblematic case of Yellow Tail (Cox and Bridwell, 2007), as well as in the introduction of Argentine and Chilean wine in these markets (Berrios and Saens, 2012).

This article analyzes which type of strategy wineries follow in Connecticut and Rhode Island: (leadership in) cost or differentiation. In the context of small wineries with a strong touristic orientation, the differentiation strategy may seem apparent, however, this article presents two hypotheses to empirically test whether it is one or the other the one that is prevalent in CT and RI wineries. Consequently, the following first (A) and second (B) hypotheses are formulated:

\section{Hypothesis A:}

The wineries tending towards a cost leadership strategy will have a better performance.

\section{Hypothesis B:}

The wineries tending towards a differentiation strategy will have a better performance.

\section{Management Capabilities and Business Performance}

The establishment of the following third hypotheses is done with the objective of confirming that the Theory of Resources and Capabilities or Resource Based View (RBV) (Barney, 1991), together with the Theory of Competitive Advantage (Porter, 1980), jointly explain the competitive advantage achieved by wineries in the states of Connecticut and Rhode Island, and ultimately the performance of these companies (Spanos and Lioukas, 2001; Ortega, 2010).

The analysis of resources and capabilities will focus on management capabilities, because of the importance they have in the company's results; it is how the manager projects his strategy and his objectives to the rest of the organization. As Teece et al. (1997) mentioned: "in short, strategic, organizational, and human resource decisions made by management lie at the heart of enterprise performance".

Management and organizational capabilities are developed at the top of the organizational chart through three functions: coordination and integration, learning, and reconfiguration (Teece et al., 1997). These capabilities are part of the routines learned and may differentiate a company, explaining why some of them 
present more efficient management than others and may become a source of competitive advantage (Teece et al., 1997).

The importance of managerial skills is based on the manager's vision and leadership (Pickett, 1998), integrating this with the strategy (Westley and Mintzberg, 1989). The management competencies include the definition of the strategy and the organizational structure at the level of design and implementation. Managers must provide a high degree of commitment, clear definition of objectives and financial resources (Pickett, 1998), and guide employees towards the shaping of business resources and competencies (Kor and Mesko, 2013).

Management resources reflect the capabilities of managers and are precursors to competitive advantage and revenue. The managerial skills are not easily exportable to other companies. Therefore, the hiring of external managers does not always have a positive effect. It is through human capital that the manager generates income by implementing the strategy and making operational decisions (Castanias and Helfat, 2001; Helfat and Martin, 2015).

Managers use their management capacity to guide the company towards cost reduction, product differentiation or a combination of both, looking for a competitive advantage. Their responsibility and management include strategic business vision, internal communication, strategic management of human resources (recruitment, job analysis, development, training, performance, and compensation), the acquisition of resources and their transformation into products and services. Through these managerial steps, they create value for the partners and owners of the company, thus being a generator of revenues and their appropriation, and a key element for the maintenance of the competitive advantage (Lado and Wilson, 1994).

The analysis of management capabilities and their connection with strategy and performance has been analyzed finding a positive relation (Spanos and Lioukas, 2001; Ortega, 2010; Welter et al., 2013). In the wine industry and wineries in the New World, management capabilities have also been related to better performance: in the Chilean wine industry, in the choice of strategies based on changes in the environment (Torres and Kunc, 2016), and in wineries of the Napa Valley in California, in which managerial skills are preeminent to adapt strategies to changes in the competitive environment (Taplin, 2006). Thus, this relates to the establishment of the third (C) hypothesis:

\section{Hypothesis C:}

In Connecticut and Rhode Island wineries, the management capabilities owned by the firm are positively related to the firm's performance.

\section{Sample and Variables}

To address the research hypotheses, and a gap in data for these two states, a survey was conducted of wineries in the states of Rhode Island and Connecticut using lists from each department of agriculture's 
winery websites as our survey universe. The states of Rhode Island and Connecticut listed 11 wineries and 36 wineries respectively (RI Department of Agriculture, 2018; CT Department of Agriculture, 2018).

All 47 wineries were contacted by e-mail introducing the project and asking them to send their responses through a digital version of the survey. Initial contacts were followed-up with a personal visit, e-mails, and phone calls to request participation in the survey. The process extended for 4 months, from July to October 2018. The final response included 3 wineries for the State of RI, a 27\% response rate, and 12 wineries for the State of CT, a 33\% response rate. This corresponds to a 32\% response between the two states, a high and representative value, and over the $14 \%$ as the order of magnitude reported by Baruch and Holtom (2008) for industrial sectors. The summary statistics of the sample characteristics are presented in Table 1.

Table 1. Summary of Statistics. Sample Characteristics.

\begin{tabular}{|c|c|c|c|c|c|}
\hline Variable & Observations & Mean & $\begin{array}{c}\text { Standard } \\
\text { Deviation }\end{array}$ & Minimum & Maximum \\
\hline Connecticut & 12 & & & & \\
\hline Rhode Island & 3 & & & & \\
\hline Age (years of operation) & 15 & 11.47 & 6.034 & 2 & 21 \\
\hline Number of permanent employees & 2 & 3.93 & 2.789 & 0 & 12 \\
\hline Production in liters of wine (2017) & 11 & $20,667.36$ & $17,892.696$ & 2,000 & 60,000 \\
\hline $\begin{array}{l}\text { Assets in dollars } \\
(1=<400 \mathrm{~K} \$ 2=>400 \mathrm{~K} \$ \text { and }<1 \mathrm{M} \$ \\
3=>1 \mathrm{M} \$ \text { and }<5 \mathrm{M} \$ 4=>5 \mathrm{M} \$ \text { and }< \\
10 \mathrm{M} \$ 5=>10 \mathrm{M} \$ \text { and }<20 \mathrm{M} \$ ; 6=>20 \\
\mathrm{M} \$ \text { and }<40 \mathrm{M} \$ ; 7=>40 \mathrm{M} \$)\end{array}$ & 1 & 2.45 & .820 & 1 & 3 \\
\hline $\begin{array}{l}\text { Billing Business } \\
(1=<50 \mathrm{~K} \$ 2=>50 \mathrm{~K} \$ \text { and }<200 \mathrm{~K} \$ ; 3= \\
>200 \mathrm{~K} \$ \text { and }<1 \mathrm{MS} ; 4=>1 \mathrm{M} \$ \text { and }< \\
5 \mathrm{M} \$ 5=>5 \mathrm{M} \$ \text { and }<10 \mathrm{M} \$ ; 6=>10 \\
\mathrm{M} \$ \text { and }<20 \mathrm{M} \$ ;=>20 \mathrm{M} \$)\end{array}$ & 10 & 2.30 & 1.059 & 1 & 4 \\
\hline $\begin{array}{l}\text { Production of red wine, white wine and } \\
\text { rosé wine } \\
(1=0 \% ; 2=>0 \% \text { and }<10 \% ; 3=>10 \% \\
\text { and }<25 \% ; 4=>25 \% \text { and }<50 \% ; 5=> \\
50 \% \text { and }<75 \% ; 6=>75 \%)\end{array}$ & & & & & \\
\hline Production of red wine & 15 & 3.60 & .986 & 1 & 5 \\
\hline Production of white wine & 15 & 4.20 & 1.320 & 1 & 6 \\
\hline Production of rosé wine & 15 & 2.27 & .884 & 1 & 4 \\
\hline $\begin{array}{l}\text { Tourist Strategies } \\
(1=\text { not considered; } 5=\text { major, constant } \\
\text { emphasis })\end{array}$ & & & & & \\
\hline $\begin{array}{l}\text { Design a touristic appeal to attract } \\
\text { costumers }\end{array}$ & 15 & 3.27 & 1.223 & 1 & 5 \\
\hline Being part of a Wine Trail & 15 & 3.67 & 1.397 & 1 & 5 \\
\hline \multicolumn{6}{|l|}{$\begin{array}{l}\text { Market sales } \\
(1=0 \% ; 2=>0 \% \text { and }<10 \% ; 3=>10 \% \\
\text { and }<25 \% ; 4=>25 \% \text { and }<50 \% ; 5=> \\
50 \% \text { and }<75 \% ; 6=>75 \%)\end{array}$} \\
\hline Sales in the same region & 14 & 6.00 & 0.000 & 6 & 6 \\
\hline Sales directly to consumer & 12 & 3.25 & 2.301 & 1 & 6 \\
\hline
\end{tabular}




\begin{tabular}{|l|r|r|r|r|r|}
\hline Number of visitors & 9 & $6,890.56$ & $6,246.823$ & 15 & 17,500 \\
\hline
\end{tabular}

Source: Computed by authors using survey data.

In terms of performance and management capabilities associated, the analysis of the competitive advantage of the Connecticut and Rhode Island wineries was conducted using questions and scales that had been used and validated in previous studies (Spanos and Lioukas, 2001; Ortega 2010; Ferrer et al., 2018a). The variables, Likert scale with five levels and summary statistics are presented in Table 2.

Table 2. Summary of Statistics. Performance and Managerial Capabilities Variables.

\begin{tabular}{|c|c|c|c|c|c|}
\hline Variable & Observations & Mean & $\begin{array}{c}\text { Standard } \\
\text { Deviation }\end{array}$ & Minimum & Maximum \\
\hline \multicolumn{6}{|l|}{ Performance $(1=$ low; high=5) } \\
\hline Sales volume, in dollars & 14 & 3.07 & 1.141 & 1 & 5 \\
\hline Growth in sales volume, in dollars & 14 & 3.00 & 1.109 & 2 & 5 \\
\hline Market share, $\%$ over sales in dollars & 13 & 2.77 & .832 & 2 & 5 \\
\hline $\begin{array}{l}\text { Growth in market share, over sales in } \\
\text { dollars }\end{array}$ & 13 & 2.77 & .927 & 2 & 5 \\
\hline Number of the visitors to the winery & 14 & 3.07 & .997 & 1 & 5 \\
\hline $\begin{array}{l}\text { Profitability Performance. Profit } \\
\text { margin }\end{array}$ & 14 & 2.64 & 1.082 & 1 & 4 \\
\hline $\begin{array}{l}\text { Profitability Performance. Return on } \\
\text { own capital }\end{array}$ & 14 & 2.86 & 1.027 & 1 & 4 \\
\hline Profitability Performance. Net profits & 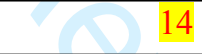 & 2.64 & 1.008 & 1 & 4 \\
\hline \multicolumn{6}{|l|}{ Managerial Capabilities $(1=$ low; high=5) } \\
\hline Managerial competencies & 14 & 3.50 & .650 & 3 & 5 \\
\hline Knowledge and skills of employees & 14 & 3.57 & .852 & 2 & 5 \\
\hline Work climate & 14 & 3.86 & .770 & 3 & 5 \\
\hline Efficient organisational structure & 14 & 3.07 & .730 & 2 & 4 \\
\hline Coordination & 14 & 3.14 & .770 & 2 & 4 \\
\hline Strategic planning & 14 & 3.29 & .914 & 2 & 5 \\
\hline Ability to attract creative employees & 14 & 3.29 & .825 & 2 & 5 \\
\hline
\end{tabular}

Source: Computed by authors using survey data.

The digital survey covers a series of questions related to the analysis of their business strategy. The method used is Robinson and Pearce (1988) twenty-two questions in which the business strategy is captured through a Likert scale with five levels; RI and CT wineries evaluate themselves concerning different business development efforts where 1 is "not utilized" and 5 is "primary, constantly utilized".

These 22 questions capture the business strategies used (Dess and Davis, 1980; Robinson and Pearce, 1988) and allow to know what the competitive options for these RI and CT wineries are: cost or differentiation. The company also projects through these competitive methods one of the generic strategies of the four main strategies defined by Robinson and Pearce (1988): efficiency, service / high price, innovation and development, and marketing. The analysis of the strategies of Robinson and Pearce adds more information, 
detail and clarification of how Porter's generic strategies are developed in the company (Spanos and Lioukas, 2001; Camisón et al., 2007; Ortega, 2010; Ferrer et al., 2018a; among others). The variables and summary statistics are presented in Table 3.

Table 3. Summary Statistics. Twenty-two Questions to Capture Robinson and Pearce Variables.

\begin{tabular}{|c|c|c|c|c|c|}
\hline Variable & Observations & Mean & $\begin{array}{l}\text { Standard } \\
\text { Deviation } \\
\end{array}$ & Minimum & Maximum \\
\hline \multicolumn{6}{|l|}{$\begin{array}{l}\text { Twenty-two Strategy Questions from } \\
\text { Robinson and Pearce } \\
\text { (1= not considered; } 5=\text { major, constant } \\
\text { emphasis) }\end{array}$} \\
\hline Pricing below competitors & 15 & 2.47 & 1.246 & 1 & 5 \\
\hline New product development & 15 & 3.60 & 1.056 & 2 & 5 \\
\hline Broad product range & 14 & 3.43 & 1.089 & 2 & 5 \\
\hline Extensive customer service capabilities & 15 & 3.40 & 1.404 & 1 & 5 \\
\hline $\begin{array}{l}\text { Specific efforts to insure a pool of } \\
\text { highly trained experienced personnel }\end{array}$ & 15 & 2.93 & 1.223 & 1 & 5 \\
\hline $\begin{array}{l}\text { Extremely strict product quality control } \\
\text { procedures }\end{array}$ & 15 & 3.53 & 1.060 & 2 & 5 \\
\hline $\begin{array}{l}\text { Continuing, overriding concern for } \\
\text { lowest cost per unit }\end{array}$ & 15 & 2.53 & .915 & 1 & 5 \\
\hline $\begin{array}{l}\text { Maintaining high inventory } \\
\text { levels (disregard the derivative of the } \\
\text { aging of the product) }\end{array}$ & 15 & 2.73 & 1.100 & 1 & 5 \\
\hline Narow, limited range of products & 15 & 2.20 & 1.082 & 1 & 5 \\
\hline Building brand identification & 15 & 3.67 & 1.175 & 1 & 5 \\
\hline $\begin{array}{l}\text { Developing and refining existing } \\
\text { products }\end{array}$ & 14 & 3.79 & 1.188 & 1 & 5 \\
\hline $\begin{array}{l}\text { Strong influence over channels } \\
\text { distribution }\end{array}$ & 15 & 1.80 & 1.146 & 1 & 5 \\
\hline $\begin{array}{l}\text { Major effort to insure availability of } \\
\text { raw materials }\end{array}$ & 15 & 2.67 & 1.175 & 1 & 5 \\
\hline $\begin{array}{l}\text { Major expenditure on production } \\
\text { process-oriented R\&D }\end{array}$ & 15 & 2.40 & 1.183 & 1 & 5 \\
\hline Only serve specific geographic markets & 15 & 3.40 & 1.298 & 1 & 5 \\
\hline $\begin{array}{l}\text { Promotion advertising expenditures } \\
\text { above the industry average }\end{array}$ & 15 & 2.87 & .990 & 1 & 5 \\
\hline $\begin{array}{l}\text { Emphasis on the manufacturing of } \\
\text { specialty products }\end{array}$ & 15 & 2.93 & 1.163 & 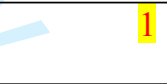 & 5 \\
\hline $\begin{array}{l}\text { Concerted effort to build reputation } \\
\text { within industry }\end{array}$ & 15 & 3.60 & .986 & 2 & 5 \\
\hline Innovation in manufacturing process & 14 & 2.86 & 1.351 & 1 & 5 \\
\hline $\begin{array}{l}\text { Products in higher-priced market } \\
\text { segments }\end{array}$ & 15 & 2.93 & 1.100 & 1 & 5 \\
\hline $\begin{array}{l}\text { Products in lower-priced market } \\
\text { segments. }\end{array}$ & 15 & 2.53 & 1.125 & 1 & 4 \\
\hline $\begin{array}{l}\text { Innovation in marketing techniques and } \\
\text { methods }\end{array}$ & 15 & 3.07 & 1.033 & 1 & 5 \\
\hline
\end{tabular}

Source: Computed by authors using survey data. 


\section{Methodology}

To understand the relationship between Porter's generic strategies, differentiation and low cost, with performance, as well as the relationship between performance and managerial capabilities, three Bayesian univariate regressions are developed (first step). In a second step, it is analyzed more in detail, on the one hand, which of the four strategies defined by Robinson and Pearce (efficiency; service / high price; innovation and development; marketing) is more related to performance and, secondly, which of the managerial capabilities (managerial competencies; knowledge and skills of employees; work climate; efficient organizational structure; coordination; strategic planning; ability to attract creative employees) is more related to performance.

\subsection{First Step: Bayesian Univariate Regression}

The performance of univariate regressions is chosen for two major reasons; a. to achieve greater reliability in the model given the number of responses, and $b$. because is more appropriate when the number of cases is low, and the normality of the variables cannot be assured (Block et al., 2011). The model developed can test the three hypotheses, whether generic strategies, cost or differentiation, and/or management capabilities explain CT and RI wineries' business performance.

The proposed model of analysis is as follows:

$$
Y_{j}=\beta_{0}+\beta_{1} X+e_{i}
$$

where the dependent variable (DV), $Y_{j}$, is the performance value for the company " $j$ ", measured as the average of the different items contemplated in the answers related to performance (see Table 2); $\beta_{0}$ is the constant; $\beta_{1}$, the coefficient of the independent variable; and $e_{i}$ is the error or the residual of the proposed model.

As three models are developed, the independent variable (IV) is: 1) in the first case the differentiation strategy, defined by answers that stated a "considerable emphasis or major, constant emphasis" to the question related to selling "products in higher-priced market segments", 2) in the second case the low-cost strategy, defined by answers that stated a "considerable emphasis or major, constant emphasis" to the question related to selling "products in lower-priced market segments", and 3) in the third case managerial capabilities, defined as the average of the seven answers to the questions that define them (see Table 2).

\subsection{Second Step: Comparison Between Independent Samples}

To determine which specific factors (see Tables 2 and 3) explain the performance of the CT and RI wineries, two comparisons are developed, one for Robinson and Pearce strategies and another for managerial capabilities. The sample has been divided into two halves, the first sample is made up of those companies that obtain the best results in business performance (Sample A) and the second one is made up of those companies that obtains the worse results (Sample B). The classification has been carried out with the performance averages, using the variables defined in Table 2. 


\section{Results}

The process of analysis of the proposed hypotheses is carried out in two phases; first, a Bayesian univariate regression is performed for the two types of generic Porter Strategies (Low-Cost and Differentiation) and the Management Capabilities. Subsequently and following the Strategies defined by Robinson and Pearce (1988) (see Table 4, below), a Kruskall-Wallis Test is performed defining which of these Strategies are associated to the best performance, defining two independent samples, wineries that perform better than their competitors (Sample A), and wineries that perform worse than their competitors (Sample B). Through another non-parametric Kruskall-Wallis Test, the characteristics of the Management Capabilities is determined by defining the same two independent samples, wineries that perform better than their competitors (Sample A), and wineries that perform worse than their competitors (Sample B).

Table 4. Robinson and Pearce (1988) Strategies.

Pattern of Classification.

\begin{tabular}{|c|c|c|}
\hline $\begin{array}{l}\text { Pattern } \\
\text { Classification }\end{array}$ & $\begin{array}{l}\text { Competitive methods associated with } \\
\text { each pattern of strategic behavior. } \\
\text { Questions of the scale. }\end{array}$ & Comments and interpretation \\
\hline \multirow[t]{5}{*}{ Efficiency } & Seek to ensure trained personnel & \multirow{5}{*}{$\begin{array}{l}\text { Each competitive method is } \\
\text { consistent with an effort to ensure } \\
\text { efficient, cost-effective operations }\end{array}$} \\
\hline & Pursue strict quality control & \\
\hline & Emphasize lowest cost per unit & \\
\hline & $\begin{array}{l}\text { Push innovation in manufacturing } \\
\text { processes }\end{array}$ & \\
\hline & Innovation in marketing techniques & \\
\hline \multirow[t]{5}{*}{ Service } & $\begin{array}{l}\text { No concern for pricing below } \\
\text { competitors (negative load) }\end{array}$ & \multirow{5}{*}{$\begin{array}{l}\text { Consistent concern with extensive } \\
\text { service to customers in higher- } \\
\text { priced markets with the } \\
\text { development of an industry } \\
\text { reputation }\end{array}$} \\
\hline & Extensive customer service & \\
\hline & Build reputation in industry & \\
\hline & Serve high-priced market segments & \\
\hline & $\begin{array}{l}\text { Avoid low-priced market segments } \\
\text { (negative load) }\end{array}$ & \\
\hline \multirow{4}{*}{$\begin{array}{l}\text { Product innovation } \\
\text { and development }\end{array}$} & New product development & \multirow{4}{*}{$\begin{array}{l}\text { Seeks to emphasize specialized } \\
\text { products and new developments or } \\
\text { refinements based in part on } \\
\text { process R\&D }\end{array}$} \\
\hline & Develop and refine existing products & \\
\hline & Emphasize specialty products & \\
\hline & Process-oriented R\&D & \\
\hline \multirow{4}{*}{$\begin{array}{l}\text { Brand /channel } \\
\text { influence } \\
\text { (Marketing) }\end{array}$} & Build brand identification & \multirow{4}{*}{$\begin{array}{l}\text { Focus on brand recognition and } \\
\text { strong influence over channels } \\
\text { through efforts like product } \\
\text { development and new marketing } \\
\text { techniques }\end{array}$} \\
\hline & Influence channels of distribution & \\
\hline & New product development & \\
\hline & Innovation in marketing techniques & \\
\hline
\end{tabular}




\subsection{First Step: Bayesian Univariate Regression}

The results of the regression for the three models are shown in Table 5 (below). The acceptance rate has a value of 0.35 for the first model, 0.29 for the second model, and 0.35 for the third. Thus, it may be inferred that management capabilities and the differentiation strategy (benefit leadership) have an impact on business performance. However, the likelihood that management capabilities have a positive impact in business performance is more than $99 \%$, and it is almost at the $93 \%$ level for the differentiation strategy, showing that eventually, management capabilities have a greater impact on business performance. The lowprice strategy cannot be related to the winery's performance and its likelihood to have a positive impact on business performance is less than $16 \%$. Therefore, this is the confirmation of Hypotheses B ("The wineries tending towards a differentiation strategy will have a better performance") and C ("In Connecticut and Rhode Island wineries, the management capabilities owned by the firm are positively related to the firm's performance"), and the rejection of Hypothesis $A$.

Table 5. Bayesian Univariate Regressions.

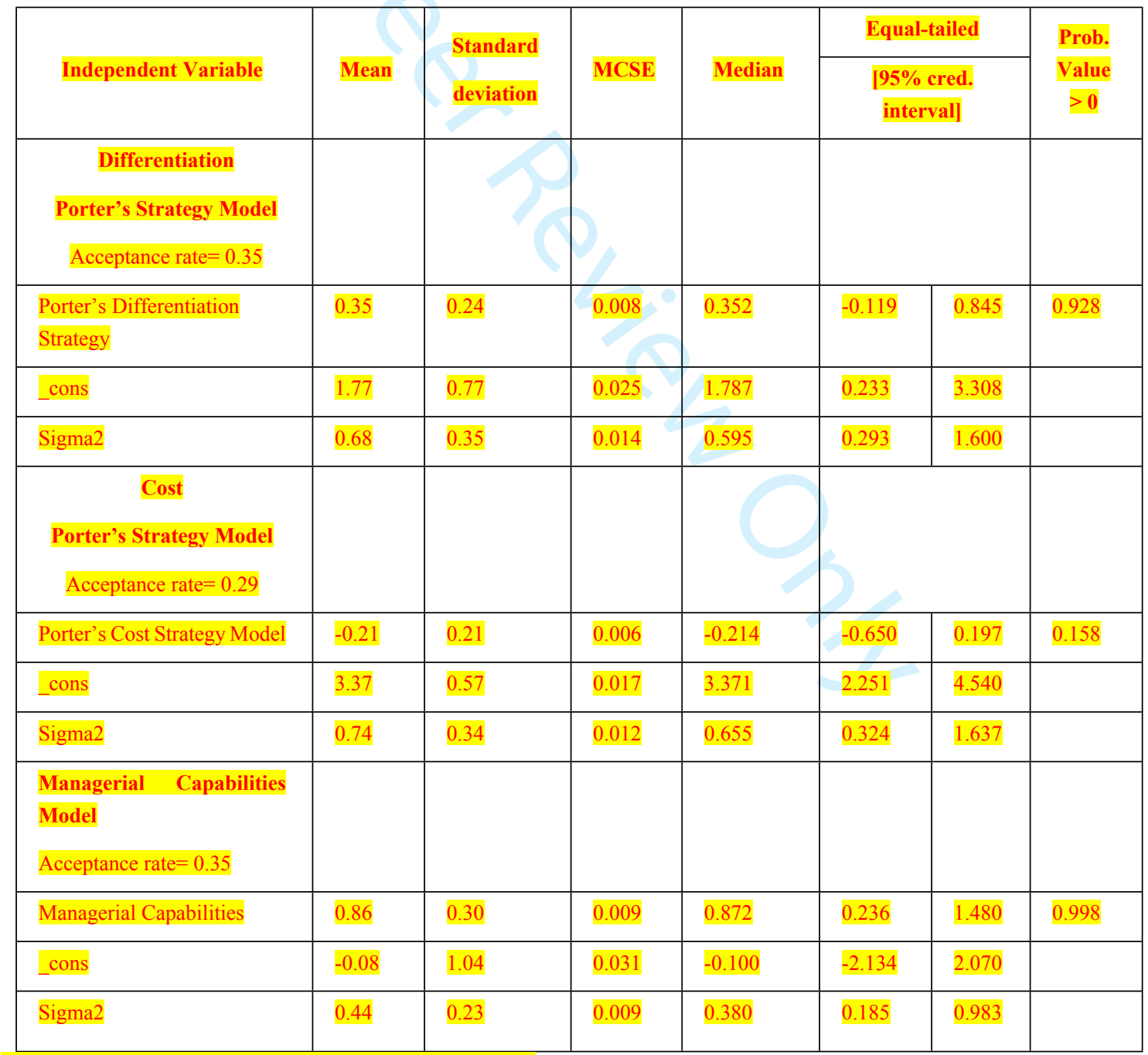

Source: Computed by authors using survey data.

\subsection{Second Step: Comparison Between Independent Samples}


Table 6 (below) displays the Kruskall-Wallis equality of population rank test done for the four types of Robinson and Pearce strategies, for the two defined samples, wineries that perform better than their competitors (Sample A), and wineries that perform worse than their competitors (Sample B).

Table 6. Kruskall-Wallis Equality of Population Rank for Robinson and Pearce Strategies.

\begin{tabular}{|c|c|c|c|c|c|c|}
\hline \multirow[b]{2}{*}{ Variables } & \multicolumn{2}{|c|}{ Sample A } & \multicolumn{2}{|c|}{ Sample B } & \multirow{2}{*}{$\begin{array}{c}\text { Chi- } \\
\text { squared } \\
\end{array}$} & \multirow{2}{*}{ Probability } \\
\hline & Observations & Rank Sum & Observations & Rank Sum & & \\
\hline Efficiency & 7 & 66.00 & 7 & 51.00 & 2.182 & 0.3359 \\
\hline Service & 7 & 70.50 & 7 & 47.50 & 3.974 & 0.1371 \\
\hline Innovation & 7 & 55.00 & 7 & 54.00 & 0.509 & 0.7752 \\
\hline Marketing & 7 & 51.00 & 7 & 55.00 & 2.040 & 0.3605 \\
\hline
\end{tabular}

Table 6 (above) shows the Service Strategy as the highest one related to the better performance of the wineries in CT and RI, even with a not very good significance $(0.137)$ and related to the way these wineries eventually achieve their Differentiation strategy.

To determine which management capabilities are related to a better performance of CT and RI wineries, Table 7 (below) displays the Kruskall-Wallis equality of population rank test done for the management capabilities, for the two defined samples, wineries that perform better than their competitors (Sample A), and wineries that perform worse than their competitors (Sample B).

This analysis reflects that the following management capabilities have resulted key elements in their performance and present values with a high level of statistical significance: efficient organizational structure (0.010) and coordination (0.039), with medium level of statistical significance: ability to attract creative employees (0.053) and strategic planning (value is lower than 0.10: 0.093). These management capabilities (efficient organizational structure, coordination, the ability to attract creative employees, and strategic planning) are the performance drivers of the wineries of RI and CT.

Table 7. Kruskall-Wallis Equality of Population Rank for Management Capabilities.

\begin{tabular}{|c|c|c|c|c|c|c|}
\hline \multirow[b]{2}{*}{ Variables } & \multicolumn{2}{|c|}{ Sample A } & \multicolumn{2}{|c|}{ Sample B } & \multirow{2}{*}{ Chi-squared } & \multirow{2}{*}{ Probability } \\
\hline & Observations & Rank Sum & Observations & Rank Sum & & \\
\hline $\begin{array}{l}\text { Managerial } \\
\text { competencies }\end{array}$ & (2 & 60.50 & 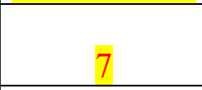 & 44.50 & 1.354 & 0.2445 \\
\hline $\begin{array}{l}\text { Knowledge } \\
\text { and skills of } \\
\text { employees }\end{array}$ & 7 & 60.00 & 7 & 45.00 & 1.142 & 0.2853 \\
\hline Work climate & 7 & 63.00 & 7 & 42.00 & 2.068 & 0.1504 \\
\hline $\begin{array}{l}\text { Efficient } \\
\text { organizational } \\
\text { structure }\end{array}$ & 7 & 71.00 & 7 & 34.00 & 6.604 & 0.0102 \\
\hline Coordination & 7 & 67.50 & 7 & 37.50 & 4.221 & 0.0399 \\
\hline $\begin{array}{l}\text { Strategic } \\
\text { planning }\end{array}$ & 7 & 65.00 & 7 & 40.00 & 2.824 & 0.0929 \\
\hline $\begin{array}{l}\text { Ability to } \\
\text { attract }\end{array}$ & 7 & 66.50 & 7 & 38.50 & 3.753 & 0.0527 \\
\hline
\end{tabular}




\section{Conclusion}

This article analyzes the drivers that explain the competitive advantage of companies in an industry where two business objectives, the development of a food product and the creation of a service, contribute to generate loyalty to their customers. The article focuses on the analysis of wineries in the states of Connecticut and Rhode Island, in the northeastern U.S., a New World area of the wine industry. The small wineries present in these states develop a double model of wine and tourism, favored by their proximity to big cities like New York and Boston.

To capture the environment and business reality of these wineries in CT and RI, a survey directed to all of them was designed and administered, a third of them responded. The survey collected data on their business strategies, management capabilities, and performance, intending to understand the factors that define the achievement of their competitive advantage.

The article assumes that the competitive advantage is reached by those companies that have a better performance than their competitors (Amadieu and Viviani, 2010; Simon-Elorz et al., 2015) and that this competitive advantage may be found following the analysis of two theories, the Theory of the Competitive Advantage of Porter (1980) and the Theory of Resources and Capabilities of Barney (1991). The article also assumes that these theories are not two opposed options but that both together better explain business excellence (Rivard et al., 2006; Rapp et al. al., 2010; Takata, 2016; Rosenberg and Ferlie, 2016; Chuang and Lin, 2017; Ferrer et al., 2018a).

In terms of business strategy, the model by Robinson and Pearce (1988) has been used; the analysis of business behaviors is done through 22 questions that assess the orientation of the company towards the two generic strategies of Porter (1980), leadership in differentiation and leadership in costs. At the same time, the model defines the existence of four derived strategies linked with the previous two: efficiency, service, innovation, and marketing (Robinson and Pearce, 1988).

To study the resources and managerial skills the article focuses on management capabilities, due to the importance they have in the management of wineries (Kunc, 2007; Charles et al., 2008; Duarte and Bresnan, 2016; Torres and Kunc, 2016; Ferrer et al., 2018a). The article uses seven management capabilities evaluated in previous studies (Spanos and Lioukas, 2001; Ortega, 2010; Ferrer et al., 2018a): strategic planning, managerial competencies, efficient organizational structure, coordination, knowledge and skills of employees, work climate, and ability to attract creative employees.

The article reaffirms the existence of the synergistic effect between strategies and resources and capabilities in the explanation of how companies achieve their competitive advantage. The results for the wineries of CT and RI show that their own management capabilities and the pursuit of a strategy of differentiation 
better explain their performance, but eventually, their managerial skills have a major impact on performance.

The article shows that the role played by the entrepreneur's abilities to lead the company, to coordinate its resources, to define what aspects should be promoted, to make the strategy a reality, is relatively more important than the strategic intent pursued (differentiation through service). Winery owners and managers in $\mathrm{CT}$ and RI value and work towards having a coordinated, efficient, and touristic-oriented organizational structure that can attract creative employees. The manager's fundamental role in small wineries in the New World implies making constant adaptive decisions in matters of production and costs, distribution, marketing, and consumers (Kunc, 2007). These entrepreneurs must recognize marketing opportunities, this is of ultimate importance for them to become true leaders of their wineries and survive (Torres and Kunc, 2016).

Besides the importance of the management capabilities in the explanation of performance of these wineries, the fact that the differentiation strategy is also linked to a better performance has already been highlighted by D'Aveni et al. (2010) and Brenes et al. (2014); the authors defend the existence of a single business success strategy in sectors with high competitiveness, such as the wine sector. In the specific case of the wine industry and particularly in the New World, the differentiation strategy, based on the presentation of a product that increases consumer satisfaction, has also and already been pointed out as an explanatory factor of performance by various authors (Remaud and Couderc, 2006; Taplin, 2006; Cox and Bridwell, 2007; Berríos and Saens, 2012).

Along the same lines, the article corroborates how among the different strategies linked and cited by Robinson and Pearce (1988), the service strategy stands out with the most relevance to explain how wineries in these states achieve their differentiation strategy. Hence, these CT and RI small wineries draw attention through differentiation policies very linked to the development of the product-tourism service strategy. This certainly characterizes the wine sector in CT and RI where wineries base their offering on a unique experience connected to the tasting experience and the rustic territory where the structural dimensions are cellar-door sales, wine trails, and festivals, more than in a differentiation strategy based on wine branding or varietal wines (Kunc, 2007; Villanueva and Moscovici, 2016). The expansion and enhancement of the product are oriented to the presentation of the winery as a place of touristic visits, in which family celebrations, sports activities, yoga classes, concerts, or dance classes can be held. If the winery can present itself as a place of greater attractiveness, the closer it is to the firm to achieve its competitive advantage.

The article presents some limitations, the most important being the size of the sample; even though an important percentage of the $\mathrm{CT}$ and RI wineries replied to the survey, definitive conclusions are difficult to be drawn. Also, the use of subjective scales in the definition of performance is another element that may limit the article conclusions. However, these scales have been used in various studies that demonstrated their convergence with objective scales (Wall et al., 2004; Sirmon et al., 2010), they were used in numerous empirical studies (Spanos and Lioukas, 2001; Ortega, 2010; Camisón and Villar-López, 2014; Prajogo, 2016; Ferrer et al., 2018a). 
The article opens the door to analyze the competitiveness of other wineries in other U.S. states, and to make a map of the competitiveness of the wine sector in a wine country as important as the U.S.

\section{References}

Amadieu. P. \& Viviani. J. L. (2010). Intangible effort and performance: the case of the French wine industry. Agribusiness. 26(2). 280-306.

Amit, R., \& Schoemaker, P. J. (1993). Strategic assets and organizational rent. Strategic management journal, 14(1), 33-46.

Ansoff, H. I. (1965) Corporate strategy: business policy for growth and expansion. McGraw-Hill Book.

Barney, J. (1991). Firm resources and sustained competitive advantage. Journal of management, 17(1), 99-120.

Barney, J. B., Ketchen, D. J. \& Wright, M. (2011). The future of resource-based theory revitalization or decline? Journal of management, 37(5), 1299-1315.

Baruch, Y., \& Holtom, B. C. (2008). Survey response rate levels and trends in organizational research. Human Relations, 61(8), 1139-1160.

Berríos, R. \& Saens, R. (2012). The country brand trap. Cepal Review, 106(15), 75-88.

Besanko, D., Dranove, D., Shanley, M., \& Schaefer, S. (2009). Economics of strategy. John Wiley \& Sons.

Block, J. H., Jaskiewicz, P. \& Miller, D. (2011). Ownership versus management effects on performance in family and founder companies: A Bayesian reconciliation. Journal of Family Business Strategy, 2(4), 232-245.

Brenes, E. R., Montoya, D. \& Ciravegna, L. (2014). Differentiation strategies in emerging markets: The case of Latin American agribusinesses. Journal of Business Research, 67(5), 847-855.

Bruwer, J. (2003). South African wine routes: some perspectives on the wine tourism industry's structural dimensions and wine tourism product. Tourism management, 24(4), 423-435.

Byrd, E. T., Canziani, B., Hsieh, Y. C. J., Debbage, K. \& Sonmez, S. (2016). Wine tourism: Motivating visitors through core and supplementary services. Tourism Management, 52, 19-29.

Camisón, C., Simón, F. G. \& Marqués, D. P. (2007). Estrategias competitivas y desempeño empresarial: estudio comparativo de los modelos de Robinson \& Pearce y Miles \& Snow en el sector hotelero español. Investigaciones Europeas de dirección y economía de la empresa, 13(3), 161-182.

Camisón. C. \& Villar-López. A. (2014). Organizational innovation as an enabler of technological innovation capabilities and firm performance. Journal of Business Research. 67(1). 2891-2902.

Campbell-Hunt, C. (2000). What have we learned about generic competitive strategy? A meta-analysis. Strategic Management Journal, 21(2), 127-154.

Castanias, R. P. \& Helfat, C. E. (2001). The managerial rents model: Theory and empirical analysis. Journal of Management, 27(6), 661-678.

Charters, S., Clark-Murphy, M., Davis, N., Brown, A. \& Walker, E. (2008). An exploration of managerial expertise in the Western Australian wine industry. International Journal of Wine Business Research, 20(2), 138-152.

Chuang, S. H. \& Lin, H. N. (2017). Performance implications of information-value offering in e-service systems: Examining the resource-based perspective and innovation strategy. The Journal of Strategic Information Systems, 26(1), 22-38.

Cohn, H. S. \& Davis, E. (2009). Stopping the Wind that Blows and the Rivers that Run: Connecticut and Rhode Island Reject the Prohibition Amendment. QLR, 27, 327.

CT Department of Agriculture (2018). "Wineries of Connecticut" at www.ct.gov/doag/cwp Accessed November 2018.

Cox, J. \& Bridwell, L. (2007). Australian companies using globalization to disrupt the ancient wine industry. Competitiveness Review: An International Business Journal, 17(4), 209-221.

D'Aveni, R. A., Dagnino, G. B. \& Smith, K. G. (2010). The age of temporary advantage. Strategic Management Journal, 31(13), 1371-1385.

Dess, G. G. \& Davis, P. S. (1984). Porter's (1980) generic strategies as determinants of strategic group membership and organizational performance. Academy of Management journal, 27(3), 467-488.

Duarte Alonso, A. \& Bressan, A. (2016). "A resource-based view of the firm and micro and small Italian wine firms." International Journal of Wine Business Research 28.4, pp. 349-368.

Ferrer-Lorenzo, J. R., Abella-Garcés, S. \& Maza-Rubio, T. (2017). "Competitive advantage differences between firms belonging to a business group and independent companies in the Spanish wine industry." Economía Agraria y Recursos Naturales-Agricultural and Resource Economics 17.2; pp. 105-132.

Ferrer Lorenzo, J. R., Maza Rubio, M. T. \& Abella Garcés, S. (2018a) "The competitive advantage in business, capabilities and strategy. What general performance factors are found in the Spanish wine industry?" Wine Economics and Policy (in press).

Ferrer Lorenzo, J. R., Maza Rubio, M. T. \& Abella Garcés, S. (2018b). Capacidades y estrategias de Miles y Snow en el sector del vino en Espana. Grupos vs. Bodegas independientes. Revista Espanola de Estudios Agrosociales y Pesqueros, n250, pp. 95-125.

Grant, R. M. (2010). Contemporary strategy analysis: Text and cases edition. John Wiley \& Sons.

Helfat, C. E. \& Martin, J. A. (2015). Dynamic managerial capabilities: Review and assessment of managerial impact on strategic change. Journal of Management, 41(5), 1281-1312.

Kor, Y. \& Mesko, A. (2013). Dynamic managerial capabilities: Configuration and orchestration of top executives' capabilities and the firm's dominant logic. Strategic Management Journal, 34(2), 233-244. 
Kunc, Martin H. (2007). "A survey of managerial practices in the small to medium Chilean wineries." Journal of Wine Research 18.2, pp. 113-119.

Lado, A. A. \& Wilson, M. C. (1994). Human resource systems and sustained competitive advantage: A competencybased perspective. Academy of management review, 19(4), 699-727.

Ortega, M. J. (2010). Competitive strategies and firm performance: Technological capabilities' moderating roles. Journal of Business Research, 63(12), 1273-1281.

Overton, J. \& Banks, G. (2015). "Conspicuous production: Wine, capital and status." Capital \& Class 39.3: 473-491.

Pickett, L. (1998). Competencies and managerial effectiveness: Putting competencies to work. Public Personnel Management, 27(1), 103-115.

Porter, M. E. (1985). Competitive advantage: creating and sustaining superior performance. 1985. New York: FreePress.

Porter, M. (1980). Techniques for analyzing industries and competitors. Competitive Strategy. New York: FreePress.

Prajogo, D. I. (2016). The strategic fit between innovation strategies and business environment in delivering business performance. International Journal of Production Economics, 171, 241-249.

Rapp, A., Trainor, K. J. \& Agnihotri, R. (2010). Performance implications of customer-linking capabilities: Examining the complementary role of customer orientation and CRM technology. Journal of Business Research, 63(11), 1229-1236.

Remaud, H. \& Couderc, J. P. (2006). Wine business practices: a new versus old wine world perspective. Agribusiness: An International Journal, 22(3), 405-416.

RI Department of Agriculture (2018). "Wineries of RI" at www.dem.ri.gov Accessed November 2018.

Rivard, S., Raymond, L. \& Verreault, D. (2006). Resource-based view and competitive strategy: An integrated model of the contribution of information technology to firm performance. The Journal of Strategic Information Systems, 15(1), 29-50.

Robinson, R. B. \& Pearce, J. A. (1988). Planned patterns of strategic behavior and their relationship to business-unit performance. Strategic Management Journal, 9(1), 43-60.

Rosenberg Hansen, J. \& Ferlie, E. (2016). Applying strategic management theories in public sector organizations: Developing a Typology. Public Management Review, 18(1), 1-19.

Simon-Elorz. K., Castillo-Valero. J. S. \& Garcia-Cortijo. M. C. (2015). Economic Performance and the Crisis: Strategies Adopted by the Wineries of Castilla-La Mancha (Spain). Agribusiness. 31(1). 107-131.

Sirmon, D. G., Hitt, M. A., Arregle, J. L. \& Campbell, J. T. (2010). The dynamic interplay of capability strengths and weaknesses: investigating the bases of temporary competitive advantage. Strategic Management Journal, 31(13), 1386-1409.

Spanos, Y. E. \& Lioukas, S. (2001). An examination into the causal logic of rent generation: contrasting Porter's competitive strategy framework and the resource-based perspective. Strategic management journal, 22(10), 907-934.

Swaminathan, A. (1995). The proliferation of specialist organizations in the American wine industry, 1941-1990. Administrative Science Quarterly, 653-680.

Takata, H. (2016). Effects of industry forces, market orientation, and marketing capabilities on business performance: An empirical analysis of Japanese manufacturers from 2009 to 2011. Journal of Business Research, 69(12), 5611-5619.

Taplin, I. M. (2006). Competitive pressures and strategic repositioning in the California premium wine industry. International Journal of Wine Marketing, 18(1), 61-70.

Teece, D. J., Pisano, G. \& Shuen, A. (1997). Dynamic capabilities and strategic management. Strategic management journal, 509-533.

Torres, J. P. \& Kunc, M. H. (2016). Market opportunity recognition in the Chilean wine industry: traditional versus relational marketing approaches. Journal of Wine Research, 27(1), 19-33.

Villanueva, E. C. \& Moscovici, D. (2016). "Sustainable wine tourism development in burgeoning regions: lessons from New Jersey and Connecticut." International Journal of Economics and Business Research 12.4: 313-333.

Wall, T. D., Michie, J., Patterson, M., Wood, S. J., Sheehan, M., Clegg, C. W. \& West, M. (2004). On the validity of subjective measures of company performance. Personnel psychology, 57(1), 95-118.

Welter, C., Bosse, D. A. \& Alvarez, S. A. (2013). The interaction between managerial and technological capabilities as a determinant of company performance: An empirical study of biotech firms. International Journal of Management, 30(1), 272.

Wernerfelt, B. (1984). A resource-based view of the firm. Strategic management journal, 5(2), 171-180.

Westley, F. \& Mintzberg, H. (1989). Visionary leadership and strategic management. Strategic management journal, 10(S1), 17-32. 